\title{
Proprioception influence in the balance of gymnastics rhythmic postural athletes.
}

\author{
Influência da propriocepção no equilíbrio postural de atletas de \\ ginastica rítmica.
}

Florisvaldo Aparecido Semeão1, Ana Claudia de Souza Hirata², Larissa Dragonetti Bertin², Rodrigo Franco de Oliveira³

\begin{abstract}
Introduction: Rhythmic gymnastics (RG) is a sport that combines art biomechanical gestures of high complexity, which requires a high level of development of physical qualities such as agility, flexibility, strength, impulsion and dexterity. In this modality studies show that injuries are attributed more articulate knees, ankles, and in some cases ends wrist sprains being the most frequently recorded in athletes in competition level. Therefore, proprioception and muscle control play a fundamental role in dynamic joint stability, since after orthopedic injuries sensorimotor some characteristics are altered and should be focused on rehabilitation programs to get a better return so the activities prior to the injury. Objective: The objective of this project is to evaluate the effect of proprioceptive training on postural balance of athletes in rhythmic gymnastics - RG, from the use of a force platform BIOMEC400 (EMG System do Brazil, Ltda SP). Method: We performed a proprioceptive training in thirty days, in two stages, moving the complexity of the exercises each phase proprioceptive training. Results: We observed that there was a significant improvement in results of training, when it was used more complex exercises and agility exercises before. Conclusion: Because it is athletes RG high performance and present a predominance of activities in one foot, protocols proprioception should be more intensively, generating a higher level of disturbance and postural imbalances.
\end{abstract}

Key words: Proprioception; athletes; postural balance.

\section{RESUMO}

Introdução: A ginástica rítmica (GR) é uma modalidade esportiva que combina arte a gestos esportivos de alta complexidade, onde requer um alto nível de desenvolvimento de habilidades físicas como: agilidade, flexibilidade, força, impulsão e destreza. Nessa modalidade estudos comprovam que as lesões mais atribuídas são em articulação de joelhos, tornozelos e alguns casos em extremidades de punho, sendo as entorses as mais registradas principalmente em atletas no nível de competição. Diante disso, a propriocepção e o controle muscular possuem papel fundamental na estabilidade articular dinâmica, sendo que após lesões musculoesqueléticas algumas características sensório-motoras são alteradas e devem ser focadas em programas de reabilitação para obter assim um melhor retorno as atividades pré-lesão. Objetivo: $O$ objetivo do presente projeto é avaliar o efeito do treinamento proprioceptivo no equilíbrio postural de atletas de Ginástica Rítmica - GR, a partir da utilização de uma Plataforma de força BIOMEC400 (EMG System do Brasil, SP Ltda). Método: Foi realizado um treinamento proprioceptivo no período de trinta dias, subdividido em duas fases, evoluindo a complexidade dos exercícios a cada fase de treinamento proprioceptivo. Resultados: Pode-se observar que houve uma melhora significativa dos resultados em relação ao treinamento, quando foi utilizado exercícios de maior complexidade e agilidade diante do protocolo. Conclusão: Por se tratar de atletas de GR de alta performance e apresentarem um predomínio de atividades em apoio unipodal, os protocolos de propriocepção devem ser de forma mais intensa, gerando um maior nível de perturbações e desequilíbrios posturais.

Palavras-chave: Propriocepção; atletas; equilíbrio postural.

\footnotetext{
Author Corresponding: Rodrigo Franco de Oliveira. Centro de Pesquisa em Ciências da Saúde. Av. Paris, 675 - Jd. Piza CEP 86041 -140 - Fone (43) 3371-9848. Londrina - PR, Brasil. Email: rfrancoli@yahoo.com.br

${ }^{3}$ Programa de mestrado e doutorado em Ciências da reabilitação UEL/UNOPAR, Programa de mestrado profissional em Exercício físico na promoção da saúde, Universidade Norte do Paraná (UNOPAR), Londrina (PR), Brazil.
}

Full list of author information is available at the end of the article.

Financial support: UNOPAR - FUNADESP

Submission date 11 September 2015; Acceptance date 14 December 2015; Online publication date 21 December 2015 


\section{INTRODUCTION}

Rhythmic Gymnastics (RG) is a sport that stands out for the elegance and beauty of movements, requiring a high level of development of physical skills, aiming at the technical perfection in execution of the bodily elements and at the handling of the apparatuses. ${ }^{(1)}$ The level of the athlete's performance in the practice of this sport, is highly dependent on the ability of motor coordination together with the flexibility level. ${ }^{(2)}$

According to $\mathrm{Gaii}^{(3)}$ the RG is a sport of infinite possibilities of bodily movements, fluently performed in harmony with music and coordinated with the management of this Olympic discipline own apparatuses, that are the rope, the hoop, the ball, the clubs and the ribbon.

In relation to this sport, studies prove that the most assigned occurrences of injuries are present in the joints of ankles, knees, shoulders and lumbar spine, considering the sprains the most recorded mainly in competition level athletes. ${ }^{(1)}$

The training of RG is based on principles of joint biomechanics, such as increasing flexibility, strength and muscle endurance gains, with little attention to the proprioceptive mechanism. Proprioceptive exercises are important for training protocols, mainly for the joints of the lower limbs, with the use of equipment such as: mattresses, foam rollers, inclined planes, rocker, trampoline, among others. ${ }^{(4,5)}$

Thus, it is necessary to highlight the importance of balance in postural control, composed by the action of visual, vestibular and the somatosensory systems. Therefore, the balance, in its turn, is a dynamic process of body posture to prevent falls, by maintaining the projection of the center of gravity within the area of the base of support of the body, which requires constant adjustments of muscular activity and joint positioning. ${ }^{(6)}$

The ability to maintain the balance of the body, along with a somatic constitution, are basic and selective criteria in rhythmic gymnastics, considering that the position of the gymnasts is based primarily on dynamic balance. ${ }^{(2)}$

So proprioception and muscle control have a key role in joint dynamic stability. After musculoskeletal injuries some sensory-motor features are changed and should be focused on training programs to get a better return to the activities prior to the injury. Proprioception is an indispensable element for the postural control, joint stability and several conscious sensations. ${ }^{(7)}$

The objective of this study was to verify the influence proprioceptive training on postural balance of Rhythmic Gymnastics - RG athletes using a BIOMEC 400 force platform - EMG System Brazil, SP, LDTA.

\section{METHOD}

The study is characterized as non-controlled case studies; being subjected to Plataforma Brasil and approved by the Ethics and Research Committee (CEP), from the institution
UNOPAR - Universidade Norte do Paraná $(512,966)$. Eight RG female athletes, with ages between 10 and 11 years old, belonging to the RG team from Universidade Norte do Paraná (UNOPAR), Londrina (PR), participated in this survey. Subjects that underwent surgical procedures or who presented musculoskeletal injuries at the level of upper and/or lower limbs, or who were in physical therapy were excluded.

After the explanation and signature of the informed consent by the legal guardians of each athlete, the implementation of the proprioceptive training protocol began; its development was based on studies from Baldaço and Leporace. ${ }^{(6,4)}$ The Protocol was executed prior to the RG daily training (Mondays, Wednesdays and Fridays), aimed at the prevention of muscular fatigue episode.

The first parameters were measured on the force platform BIOMEC 400 (EMG System of Brazil, SP Ltda); The test is to assess the Postural Balance, with unipodal and bipodal stance of right and left lower limb. Standardized protocol: bare feet, loose and relaxed arms by the sides of the body and with the cephalic segment positioned horizontally to the ground plan, open eyes directed to a fixed target (black cross $=14.5 \mathrm{~cm}$ height $\times 14.5 \mathrm{~cm}$ width $\times 4 \mathrm{~cm}$ thickness), positioned on the wall at the same height of the eyes at a $2.5 \mathrm{~m}$ front distance. Three 30-second attempts were executed, with 30 seconds of rest between them and the average was retained for the analysis of Postural Control. The balance parameters from force platform: scroll area of the center of pressure (COP) of the feet, and the average speed of oscillation of the COP on both plans anterior-posterior $\mathrm{A} / \mathrm{P}$ and medial-lateral $\mathrm{M} / \mathrm{L}$, were quantified to assess the postural control.

Preceding the application of the proprioceptive training, a data collection was carried out on BIOMEC 400 (EMG System of Brazil, SP Ltda) Force platform and then after 30 days of training, the final collection was executed.

The proprioceptive training consisted of:

Phase I: (15 days)

- Phase I: Setting a masking tape on the floor, to mark a line (12-meter distance); the athlete walks, performing normal gait on the line (3 stages of support), later with one foot in front of the other; afterwards, using the following supports: heel, toes and lateral and medial edges of the feet. (03 series - 03 repetitions).

- With mattresses on the floor overlaid by half, one over the other at various points (12-meter distance); the athlete walks, performing normal gait on the line (3 stages of support), later with one foot in front of the other; afterwards, using the following supports: heel, toes and lateral and medial edges of the feet. (03 series - 03 repetitions).

- Half foam roller on the floor, placed one in front of the other, aligned (12 meters), the athlete walks, performing the gait with one foot in front of the other, and afterwards, 
using the following supports: heel, toes and lateral and medial edges of the feet. (03 series - 03 repetitions).

- Setting up a circuit for gait, on different interleaved plans (floor mats [with and without overlapping] foam obstacles and pillows), (03 series - 06 repetitions).

- Ending with stretches of posterior muscles (ischiotibial and triceps surae) in an inclined plan supporting on the wall bar.

Phase II: (15 days)

- Setting up a circuit for gait, on different interleaved plans (floor mats [with and without overlapping] foam obstacles and pillows). Finally, use of small stepping and other obstacles to jump. (03 series - 06 repetitions).

- Start stimuli with unipodal support; athletes in a single line, aligned on a masking tape on the floor, transfer objects (devices used in training such as ball, clubs, hoop) by their sides, turning only the torso, sustaining with right leg and then with left leg;

- Afterwards execute the same previous movements, with unipodal support, on top of: mattresses, evolving into half foam roller, ending with the transfer of the apparatuses over their head.

- On unipodal support on top of the half foam roller, with the contralateral limb in a hip flexion of 45 degrees and knee in extension and ankle in plantar flexion, the athlete performs small circular motions, clockwise and counterclockwise during 30 seconds for each segment.

- On bipodal support, with knees extended, the athletes try to keep on balance boards and on balance disc.

- With the overlapping mats on the ground, the athlete in bipodal support performing jumps and little jumps, evolving into jump and rolls in the mat, in movements of the choreography.

- Ending with stretches of posterior muscles (ischiotibial and triceps surae) in an inclined plan supporting on the wall bar.

According to the proposed Protocol, when the exercise is performed safely, not presenting any difficulties for its implementation within the 30 seconds as proposed in each execution, the athletes are able to evolve to the next phase.

After phase II, the last data collection on the Force platform BIOMEC 400 (EMG System of Brazil, SP Ltda) was held.

\section{Statistical Analysis}

Initially, the Shapiro-Wilk normality test was performed, where we noted that the data showed normal distribution, therefore the descriptive statistics are presented in mean and standard deviation. To perform the comparison between the results before and after the intervention in the area of the COP, in the AP speed and in the ML speed, the paired t-test was used, in the bipedal, right unipodal and left unipodal stances. The Confidence interval of $95 \%$ and the significance level of $5 \%$ were used.

\section{RESULTS}

Table 1 shows the data of the comparison before and after the intervention in the variables areas of the COP, anteroposterior speed and medial-lateral speed, in which no statistically significant difference $(P>0.05)$ were observed in these variables.

In the analysis before and after intervention in Right Unipodal stance it was observed that in the area of the COP $(P=0.036)$ there was statistically significant difference, showing reduction after the intervention, the same found in the medial-lateral speed $(P=0.037)$. While in the anteroposterior velocity, no statistically significant difference was observed. These data are presented in table 2.

For the analysis of before and after intervention in Left Unipodal stance, no statistically significant differences were observed $(P>0.05)$. Data presented in table 03 .

\section{DISCUSSION}

According to the results obtained with the intervention, based on the proprioceptive protocol of 30 days, we can infer that the RG athletes showed a significant improvement

Table 1. Comparison pre and post intervention in position bipedal

\begin{tabular}{lcccccc}
\hline Variable & $\mathbf{N}$ & $\begin{array}{c}\text { Intervention } \\
\text { pre }\end{array}$ & SD & $\begin{array}{c}\text { Intervention } \\
\text { post }\end{array}$ & SD & p value \\
\hline Area CoP & 8 & 1.84 & 1.26 & 2.38 & 2.17 & 0.593 \\
MVeloc A/P & 8 & 1.29 & 0.29 & 2.26 & 2.95 & 0.409 \\
MVeloc M/L & 8 & 1.09 & 0.17 & 1.03 & 0.13 & 0.138 \\
\hline
\end{tabular}

standard deviation (SD)

Table 2. Comparison pre and post intervention in single leg right position

\begin{tabular}{lcccccc}
\hline Variable & $\mathbf{N}$ & $\begin{array}{c}\text { Intervention } \\
\text { pre }\end{array}$ & SD & $\begin{array}{c}\text { Intervention } \\
\text { post }\end{array}$ & SD & p value \\
\hline Area CoP & 8 & 10.46 & 3.56 & 8.69 & 2.21 & $0.036^{*}$ \\
MVeloc A/P & 8 & 4.08 & 0.77 & 3.69 & 0.96 & 0.130 \\
MVeloc M/L & 8 & 3.90 & 0.44 & 3.56 & 0.59 & $0.037^{*}$ \\
\hline
\end{tabular}

standard deviation (SD); * $\mathrm{P}<0,05-$ Teste t pareado.

Table 3. Comparison pre and post intervention in single leg left position

\begin{tabular}{lcccccc}
\hline Variable & $\mathbf{N}$ & $\begin{array}{c}\text { Intervention } \\
\text { pre }\end{array}$ & SD & $\begin{array}{c}\text { Intervention } \\
\text { post }\end{array}$ & SD & p value \\
\hline Area CoP & 8 & 10.14 & 2.62 & 9.72 & 3.16 & 0.502 \\
MVeloc A/P & 8 & 4.02 & 0.76 & 3.52 & 0.68 & 0.098 \\
MVeloc M/L & 8 & 3.89 & 0.30 & 3.55 & 0.50 & 0.118 \\
\hline
\end{tabular}

standard deviation (SD) 
in the mechanism, mainly in the variables: Area of the COP and Vel ML, in Right Unipodal stance, where all participating athletes present dominance of right lower limb. Based on current studies, it is worth noting that the force platform is a tool considered gold standard for analysis of postural balance deficits, by means of valid parameters and stabilometry measures of confidence, such as COP area, frequency and speed of displacement of the COP. ${ }^{(8,9)}$

According to Lafond ${ }^{(10)}$, in most of the suggested studies to analyze postural balance, the assessment of postural stability is done by means of bipodal support test. However, as an activity, bipodal support does not represent most of the difficulties of the postural control system to maintain ideal posture of balance as demonstrated in a condition of unipodal support, which can represent the activities of everyday life, when the requirement of performing a bipodal task to a unipodal task alternately. ${ }^{(11,12)}$

Based on these purposes, we note the fairly significant assessment of unipodal support balance used in this work, based on the sequence of exercises used during the representation of $R G$, which directly implies in the intervention process with RG athletes at competition level, aiming to advance performance levels, postural balance and neuromuscular control..$^{(11,12)}$

The development of this Protocol meets the works of Baldaço ${ }^{(6)}$, which used similar appliances and resources, such as foam blocks, mats, rocker, proprioceptive disk, balance board, trampoline.

In this study, we observe the use of a sequence of exercises of complex format, stimulating unipodal support, which produces a greater number of disruptions, reaching a gain in the responses, depending on the variables used; based on balance strategies, such as ankle and hip, that are critical to maintaining balance in different motor activities; based on the assumption that when the activity is a complex one, the postural control system features in the postural imbalances control. ${ }^{(12,13)}$

Exercises to sharpen the proprioception are made in closed chain and with small movements, since the compression stimulates the receptors present in the joints, as well as limb repositioning exercises should be performed, to stimulate the sense of joint position and neuromuscular control, according to the studies from Lephart and Henry. ${ }^{(14)}$

According to Swanik ${ }^{(15)}$ reactive neuromuscular control is reached from the exposition to series of exercises that produce unexpected situations, such as on unstable surfaces stimuli in unipodal support, as well as rhythmic stabilizations exercises, through the concept of Proprioceptive Neuromuscular Facilitation, that when performed, perfect muscle reaction control, thereby improving joint stability.

The findings obtained indicate a discreet improvement in posture stability toward medial-lateral and anteroposterior directions, when in the absence of the visual system feedback, and higher demand of proprioceptive in balance control. ${ }^{(6)}$
Given this, the findings refer to the development of proposals for evaluation and development of protocols for proprioception, proposing development and consequent enhance of postural control, as well as reducing musculoskeletal injuries.

As limitation of the present study we can point out the short time (30 days) of the Protocol, although we did get some answers in some variables, however, we suggest a follow-up time of at least 90 days of proprioceptive training and revaluations every 30 days.

\section{CONCLUSION}

When it comes to RG athletes at competition level and for displaying a predominance of activities in unipodal support, the proprioceptive protocols should be targeted more intensely, proposing a higher level of stimulations and postural imbalances. However, more studies are needed, for intervention protocols of postural balance in athletes, in accordance with their modalities, as well as protocols of longer duration.

\section{AUTHOR'S CONTRIBUTIONS}

RFO and FAS development of the research project, the study definition, contribution to the drafting of the text and approved the final version; RFO, FAS, ACSH, LDB performed the intervention of the study, contributed to the drafting of the text and approved the final version; ACSH, LDB participated in the definition of the study and statistical analysis and contributed to the drafting of the text. All authors read and approved the final version.

\section{CONFLICT OF INTEREST}

The authors declare no conflicts of interest.

\section{AUTHOR DETAILS}

'Educação Física, Universidade Norte do Paraná (UNOPAR), Londrina (PR), Brazil;

${ }^{2}$ Fisioterapia, Universidade Norte Paraná, (UNOPAR), Londrina (PR), Brazil.

\section{REFERENCES}

1. Karloh M, Santos RP, Kraeski MH, Matias TS, Kraeski D, Menezes S. Alongamento estático versus conceito Mulligan: aplicações no treino de flexibilidade em ginastas. Fisioter Mov. 2010 out/dez;23(4):523-33.

2. Poliszczuk T, Broda D. Somatic constitution and the ability to maintain dynamic body equilibrium in girls practicing rhythmic gymnastics. Pediatric Endocrinology, Diabets and Metabolism. 2010;16(2):94-99.

3. Gaio, R. Ginástica Rítmica para tú, eles e nós. In: Ginástica rítmica: da iniciação ao alto nível. Jundiaí-SP: Fontoura, 2008. p. 30-34.

4. Leporace G, Metsavaht L, Sposito MMM. Importância do treinamento da propriocepção e do controle motor na reabilitação após lesões músculoesquéleticas. Acta Fisiatr. 2009;16(3):126-131.

5. Cunha PL, Bonfim TR. Ativação eletromiográfica em exercícios sobre a prancha de equilíbrio. Fisioter Bras. 2007;8(3):192-7.

6. Baldaço FO, Cadó VP, Souza J, Mota CB, Lemos JC. Análise do treinamento proprioceptivo no equilíbrio de atletas de futsal feminino. Fisioter Mov. 2010;23(12):183-926. 
7. Filipa A, Byrnes R, Paterno MV, Myer GD, Hewett TE. Neuromuscular Training Improves Performance on the Star Excursion Balance test in Young Female Athletes. Journal of Orthopaedic \& Sports Physical Therapy. 2010;40(9): 551-8.

8. Silva RA, Martin B, Parreira RB, Teixeira DC, Amorim CF. Age-related differences in time-limit performance and force platform-based balance measures during one-leg stance. J Electromyogr Kinesiol. 2013 Jun;23(3):634-9

9. Duarte M, Freitas SMS. Revisão sobre posturografia baseada em plataforma de força para avaliação do equilíbrio. Rev. bras. fisioter. 2010; 14(3):183-92.

10. Lafond D, Corriveau H, Hebert R, Prince F. Intrasession reliability of center of pressure measures of postural steadiness in healthy elderly people. Arch Phys Med Rehabil. 2004;(85):896-901.
11. Lord SR, Sherrington C, Menz HB. Falls in older people: risk factors and strategies for prevention. New York: Cambridge University press, 2011; In (pp. 249).

12. Gil AWO, Oliveira MR, Rabello LM, Spadão AC, Macedo CG, Pires-Oliveira DAA, et al. Avaliação de diferentes tarefas de equilíbrio em atletas de handebol e futsal feminino. Ter Man. 2012;10(49):328-32.

13. Shigaki L, Rabello LM, Camargo MZ, Santos VBC, Gil AWO, Oliveira $\mathrm{MR}$, et al. Análise comparativa do equilíbrio unipodal de athetas de ginastica rítmica. Rev Bras Med Esporte. 2013;19(2):104-7.

14. Lephart SM, Henry TJ. Funcional rehabilitation for the upper and lower extremity. Orthop Clin North Am. 1995;26(3):579-92.

15. Swanik KA, Lephart SM, Swanik CB, Lephart SP, Stone DA, Fu FH. The effects of shoulder plyometric training on proprioception and selected muscle performance characteristics. J Shoulder Elbow Surg. 2002;11(6):579-86. 